\title{
HRM strategies, informality and re-regulation in East Asian employment relations
}

\author{
Sarosh Kuruvilla \\ School of Industrial and Labor Relations, Cornell University \\ Sun-wook Chung \\ Sogang University, Korea
}

\section{Introduction}

Although employment relations (defined as labour relations and human resources management (HRM)) institutions and practices generally tend to be stable over long periods of time, that cannot be said to be the case in the three largest economies of East Asia, i.e. China, Japan and South Korea (hereafter Korea), during the last two decades (see chapters 5, 7 and 8). In this contribution, we briefly review the most significant development in East Asian employment relations, i.e. the growth of a variety of non-standard employment arrangements which we subsume under the term 'informality' in all three countries. We see this growth as symptomatic of the 'extemalisation' of employment relations beyond the enterprise, a development that imposes major challenges for traditional trade unionism and for employment policy. We argue that the efforts of governments aimed at 'reregulating' employment relations to curb such 'informalisation' are evidence of an emerging 'labour protection logic' in these countries, although we remain sceptical about the effectiveness of attempts at re-regulation.

Our use of the term informal is broad and inclusive. We conceive of informal work as work that is not permanent, not always regulated by an employment contract, not always regulated by current law and not always with benefits. Thus, temporary and part-time workers (many of whom receive partial benefits) are included within the scope of our definition. The use of directly engaged contract workers is also covered by our definition. Also included is 'agency work' or 'despatched labour', the triangular employment relationship where workers are employed nominally by a labour market intermediary agency, but work at a third location that pays the agency a fee for using the worker. The primary employer in this case remains the agency, but the liability of the employer at the place of work is, in many countries, unclear. 


\section{Contextualising non-standard employment in East Asia}

The last two decades have witnessed dramatic changes in employment relations systemsi in all three countries. Perhaps the greatest commonality has been the movement towards a 'logic of competition' (Frenkel and Kuruvilla, 2002) that underlies employment relations, a movement that privileges employers' interests of 'employment flexibility' over worker's interests of employment 'stability'. During the last two decades this movement has been characterised by the adoption of flexibility oriented HRM strategies that have emphasised the use of contingent labour in response to the economic pressures of heightened global competition. The strategies of firms were encouraged and facilitated by institutional changes that permitted the use of such strategies. We focus on the changes in the institutional context in each country below.

In Japan, the economic recession beginning in the early 1990s forced the government to 'deregulate' labour laws in ways that helped firms 'adjust' to declining markets and profits, resulting in challenges to the traditional Japanese employment relations system (see chapter 7). A key deregulation development was the 1999 amendment to the law allowing contracted workers (commonly referred to in the Japanese literature as agency workers or 'despatch workers') to be employed in many industries except five areas (including manufacturing and construction). In 2004, the use of such workers was permitted in manufacturing as well, thereby allowing more manufacturing firms to make use of this flexible work arrangement. In 2007, the law which had only allowed such workers to be employed on temporary one-year contracts in the manufacturing industry was further modified to allow them to be employed on three-year contracts. As was expected, there was a major increase in the use of temporary, casual and agency workers as a result of these changes in Japan as these changes legitimised the movement away from the concept of 'lifetime employment (LTE)' that was a central pillar of Japanese employment relations. Ono (2010) documents the decrease in LTE from a high of over 30 per cent to less than 20 per cent today.

These changes occurred in conjunction with an increase in unemployment, and a continuing decline in 'countervailing protective institutions' such as labour unions and collective bargaining (see Table 13.1). The relative importance of the traditional 'Shunto' (Spring Wage Round) mechanism in national wage bargaining has declined, with the focus of wage bargaining shifting towards the enterprise level (Suzuki, 2010). Increasing differences in the profitability of enterprises, reflecting increased global 
competition, have been a major driver of this change. The influence of the national union federation RENGO has also declined during the recession, as enterprise unions have been the locus of 'adjustment' bargaining (Yoon, 2009).

The institutional changes in Korea tell a similar story, although the key impetus was the Asian financial crisis of 1997. Although a tripartite commission was formed to deal with the crisis, a key outcome of the tripartite agreement (one of the two union federations did not support this agreement) was the legitimisation of HRM strategies emphasising flexibility (Shin, 2010). As a result, most firms which had maintained Japanese-style long-term employment have abandoned lifelong employment and generous benefits and have increasingly taken on HRM strategies promoting efficiency and flexibility, specifically through the use of temporary and casual workers (Kim and Kim, 2003, Jung and Cheon, 2006). This process was accelerated by legislative changes which justified lay-offs and opened the way to diverse short-term, indirect employment practices including 'despatch labour' under the Kim (19982003) and Roh administrations (2003-8) (Lee 2011). The pro-business administration of the current President Lee (a former CEO of the Hyundai group) makes it clear that its labour agenda is job creation through labour flexibility. As such, a key agenda item in the National Employment Strategy (NES), issued in October 2011, was to expand the occupations and areas in which 'despatch labour' could be used. Furthermore, the Lee administration weakened unionism by enacting long-standing proposals in 2011 to prohibit employers from paying full-time union officials and the introduction of single bargaining agent principles. Finally, the government, public sectors (e.g. schools and post offices) and state-owned enterprises (SOEs) have expanded their use of non-standard work arrangements, as part of their restructuring efforts under the current Lee administration.

\begin{tabular}{|c|c|c|c|c|c|c|c|c|c|c|c|c|c|c|}
\hline Year & 1997 & 1998 & 1999 & 2000 & 2001 & 2002 & 2003 & 2004 & 2005 & 2006 & 2007 & 2008 & 2009 & 2010 \\
\hline $\begin{array}{l}\text { Unemployment } \\
\text { (all age groups) }\end{array}$ & $3.4^{\mathrm{n}} \%$ & 4.1 & 4.7 & 4.7 & 5.0 & 5.4 & 5.3 & 4.7 & 4.4 & 4.1 & 3.9 & 4.0 & 5.1 & 5.1 \\
\hline $\begin{array}{l}\text { Unemployment } \\
\text { (age: } 15-24 \text { ) }\end{array}$ & $6.7 \%$ & 7.7 & 9.1 & 9.1 & 9.6 & 9.9 & 10.1 & 9.5 & 8.7 & 8.0 & 7.7 & 7.2 & 9.1 & 9.4 \\
\hline $\begin{array}{l}\text { Unemployment } \\
\text { (age: } 25-34 \text { ) }\end{array}$ & $4.2 \%$ & 4.9 & 5.5 & 5.6 & 6.0 & 6.4 & 6.3 & 5.7 & 5.6 & 5.2 & 4.9 & 5.2 & 6.4 & 6.2 \\
\hline Union Density & $22.6 \%$ & 22.4 & 22.2 & 21.5 & 20.7 & 20.2 & 19.6 & 19.2 & 18.7 & 18.2 & 18.1 & 18.1 & 18.5 & 18.5 \\
\hline
\end{tabular}

Source: Ministry of Health, Labour and Welfarc, Japan Institute for Labour Policy and Training (JILPT).

In Korea as well (as Table 13.2 indicates), these changes also coincided with an increase in unemployment and a general weakening of trade union power as more Korean firms relocated production to China (see chapter 8). Korean unions did little to organise the largely increasing informal 
and 'non-standard' workforce, and the decline of large firms significantly affected union density. Importantly, unionism has always been a large firm phenomenon in Korea, although more than 80 per cent of Koreans are employed in small firms with less than 50 employees (unionism in small firms represents only 3.3 per cent of total union membership). In contrast, large firms with over 1,000 employees account for 62.5 per cent of union membership in Korea.

The Tripartite commission, important during the Asian financial crisis, has been gradually declining in importance. The Korean Confederation of Trade Unions (KCTU), the more militant labour federation, was almost never on board with the commission's activities, and gradually the commitment of both employers and the current Lee administration have rendered it toothless. In some industries, enterprise labour unions have now begun to form industry-wide bargaining organisations (Lee, 2011), although here too (with exceptions in the banking and hospital sector), their effectiveness has been limited in view of both employer and government opposition. Thus, institutional developments in Korea have been broadly similar to those in Japan, resulting in creating an environment that has encouraged firms to adopt non-standard arrangements, amidst a decline in countervailing forces such as unions and the tripartite commission.

Unlike Japan and Korea, China has seen a huge expansion in its economy during the last two decades (see chapter 5). In the Chinese case, the institutional transformation has been the break away from the rigid features of the 'iron-rice- bowl' (tie fan wan) system. As Kuruvilla et al. (2011) suggest,

in the early stages of reform, the process of "denationalisation", i.e. the withdrawal of the state in the management of state-owned enterprises and the consequent increase in managerial autonomy, the increasing diversity of ownership (the advent of private and foreign ownership), and the numerous joint ventures that are a "recombination of ownership" spawned increasing variation in employment practices, and increasing insecurity of employment, particularly as state enterprises sought HRM strategies that increased labour flexibility to be more competitive.

(Gallagher 2004: 20) 
Table /3.2 Unemployment and union density in Korea

\begin{tabular}{|c|c|c|c|c|c|c|c|c|c|c|c|c|c|c|}
\hline Year & 1997 & 1998 & 1999 & 2000 & 2001 & 2002 & 2003 & 2004 & 2005 & 2006 & 2007 & 2008 & 2009 & 2010 \\
\hline $\begin{array}{l}\text { Unemployment } \\
\text { (all age groups) }\end{array}$ & $2.6 \%$ & 7.0 & 6.3 & 4.4 & 4.0 & 3.3 & 3.6 & 3.7 & 3.7 & 3.5 & 3.2 & 3.2 & 3.6 & 3.7 \\
\hline $\begin{array}{l}\text { Unemployment } \\
\text { (age15-29) }\end{array}$ & $5.7 \%$ & 12.2 & 10.9 & 8.1 & 7.9 & 7.0 & 8.0 & 8.3 & 8.0 & 7.9 & 7.2 & 7.2 & 8.1 & 8.0 \\
\hline Union density & $12.2 \%$ & 12.6 & 11.9 & 12.0 & 12.0 & 11.6 & 11,0 & 10.6 & 10.3 & 10.3 & 10.8 & 10.5 & 10.1 & 9.8 \\
\hline
\end{tabular}

Source: Ministry of Employment and Labour.

Regional and local government responses to the numerical flexibility strategies pursued by employers were quite varied. Some local governments, to attract foreign investment, emphasised firm autonomy and labour flexibility at the expense of workers' rights, while others, facing political and social pressures, attempted to protect employment by preventing SOE firms from laying off workers. Thus, the initial movement towards informalisation was relatively uneven. As many have suggested, many foreign invested enterprises, whose competitive advantage stemmed from low costs and labour-intensive production, made use of the growing pool of migrant labour willing to work without formal contracts, while SOEs to varying degrees began to lay off workers as part of their restructuring efforts. SOE lay-offs and increased employment insecurity for SOE workers began in earnest in 1997. By the end of the restructuring period, over 30 million SOE workers had lost their jobs (Kuruvilla et al, 2011).

The second phase commenced with the 1995 Labour Law, seen by many as a decisive step by the Chinese state to 'smash the iron rice bowl' in order to accelerate the restructuring process. This reform, which permitted short-term contracts, was seen as a solution to two different problems. On the one hand, formal labour- contracts would improve the efficiency of state firms by ending the practice of lifetime employment. Second, the legalisation of labour relations through a written employment contract would reduce the potential for labour exploitation, particularly in the non-state sectors by enshrining 'certain rights and responsibilities'. As many have noted, the formalisation of the labourcontract system helped facilitate and legitimise the massive lay-offs that began in the SOE sector in 1997 (Gallagher, 2004), since termination at the end of the contract was done using the language of the law.

The transition to more informal work has 'intensified the process of "commodification and casualization of labour" (Friedman and Lee, 2010), where HRM strategies emphasising flexibility interact with the lack of effective regulation, resulted in plummeting labour standards'. There has been a 
remarkable growth in the violation of labour standards and in a decline in working conditions including long hours, low pay, lack of social insurance, wage arrears, poor safety and health, illegal firings and so forth during the 1995-2007 period (Lee, 2007). And there is rising dissatisfaction, expressed in a multifold increase in labour disputes since 1994 (Hurst, 2009). Thus, although China was growing rapidly, and did not evidence the rise in unemployment that we have seen in Korea and Japan, its countervailing institutions such as trade unions (despite their growth) did not have the power or independence to halt the decline in labour standards. Table 13.3 below shows the dramatic increase in labour disputes during the last decade or so.

Thus, in all three countries the economic pressures of a more competitive environment, combined with legislative changes, opened the door for a general decline in labour standards and a general growth in the informalisation of employment. The ability of countervailing institutions such as trade unions and opposition political parties to arrest these developments has been limited. Clearly competition and flexibility appear to be the dominant logic underlying the employment system transformation in these three countries during the last two decades. We turn in the next section to the impact of this transformation on non-standard forms of employment.

\begin{tabular}{|c|c|c|c|c|c|c|c|c|c|c|c|c|c|}
\hline Year & 1997 & 1998 & 1999 & 2000 & 2001 & 2002 & 2003 & 2004 & 2005 & 2006 & 2007 & 2008 & 2009 \\
\hline Unemployment rate* & $3.1 \%$ & 3.1 & 3.1 & 3.1 & 3.6 & 4.0 & 4.3 & 4.2 & 4.2 & 4.1 & 4.0 & 4.2 & 4.3 \\
\hline $\begin{array}{l}\text { Number of labour unions } \\
(10,000 \text { units })\end{array}$ & 51.0 & 50.4 & 50.9 & 85.9 & 153.8 & 171.3 & 90.6 & 102.0 & 117.4 & 132.4 & 150.8 & 172.5 & 184.5 \\
\hline $\begin{array}{l}\text { Number of labour } \\
\text { disputes }(10,000 \\
\text { units) }\end{array}$ & 7.2 & 9.4 & 12.0 & 13.5 & 15.5 & 18.4 & 22.6 & 26.0 & 31.4 & 31.7 & 35.0 & 69,3 & 68.4 \\
\hline
\end{tabular}

Source: China Statistical Yearbook, China Labour Statistical Yearbook

*Unemployment rate: Urban registered employment rate.

\section{The extent and nature of informal (non-standard employment) in East Asia}

As noted, our definition of 'informalisation' of employment is broad enough to encompass any movement away from permanent and stable employment and includes temporary, casual, agency, parttime and despatch workers. Each of the countries uses different definitions of what is non-standard work, hence, the data are strictly not comparable across countries. Despite these definitional differences, it is important to remember that the commonality is that all these forms represent a movement away from a stable, secure job with good benefits. 
In Japan, the proportion of people in non-standard employment has increased from $18.3 \mathrm{per}$ cent to 34.9 per cent of the employed workforce (see Table 13.4). Fully half of the non-standard group comprises part-time workers. Table 13.4 shows a dramatic increase in the number of contract workers, who account now for a third of the non-standard workers. What are called arbeito workers, now defined as temporary workers (originally it referred to the part-time work done by university students), are also growing substantially.

In particular, non-standard work has crept in to replace regular employment. Table 13.5 below shows the percentage of non-standard workers across a number of occupations in Japan and as the data suggest, even manufacturing, sales and office jobs, which were traditionally unionised and generally permanent, are now increasingly dominated by non-standard employment. In addition, the number of Freeters (or Junta), defined as the people between the ages of 15 and 34 who lack full-time employment or are unemployed, dramatically increased from 0.5 million in 1982 to 1.78 million in 2009. The trajectory of these young workers represents deviations from the basic school-to-work transition model in Japan, where students become full-time tenured workers upon graduation, with continuous vocational training provided by the company (Reiko, 2006). Although becoming a Freeter was initially a voluntary choice, it currently represents more of a forced choice for young workers in Japan because a shrinking number of Japanese companies recruit new graduates. Currently, a large proportion of young workers work at low-paying, low-skilled jobs in the service industry. And there is also growth in the 'NEET' proportion of the population (neither in employment, education and training), who work informally. Thus there is a growing pool of informal employment, encompassing casual, temporary, parttime, agency and 'despatched' workers, whose wages and working conditions are considerably below the norm.

\begin{tabular}{|c|c|c|c|c|c|c|c|c|c|c|c|c|}
\hline Year & 1988 & 1990 & 1992 & 1994 & 1996 & 1998 & 2000 & 2002 & 2004 & 2006 & 2008 & 2010 \\
\hline Regular workers (per cent) & $81.7 \%$ & 79.8 & 79.4 & 79.7 & 78.5 & 76.4 & 74.0 & 70.2 & 68.5 & 67.7 & 65.5 & 65.1 \\
\hline Non-standard workers (per cent) & $18.3 \%$ & 20.2 & 20.6 & 20.3 & 21.5 & 23.6 & 26.0 & 29.8 & 31.5 & 32.3 & 34.5 & 34.9 \\
\hline Part-time workers & $10.7 \%$ & 11.6 & 11.9 & 11.7 & 12.3 & 13.2 & 14.7 & 14.8 & 15.5 & 15.5 & 16.0 & 17.1 \\
\hline Arieito (temporary) workers & $3.8 \%$ & 4.7 & 4.9 & 5.0 & 5.7 & 6.6 & 7.3 & 6.8 & 6.5 & 6.3 & 6.4 & 6.9 \\
\hline Despatched/contracted workers & $3.8 \%$ & 3.9 & 3.8 & 3.6 & 3.6 & 3.8 & 4.0 & 8.1 & 9.5 & 10.5 & 12.0 & 10.9 \\
\hline
\end{tabular}

Source: The Statistics Burcau of the Ministry of Internal Affairs and Communications. 


\begin{tabular}{lccc} 
Table 13.5 Ratio of regular workers and non-standard workers across jobs (2007) \\
\hline Job & Regular workers & $\begin{array}{l}\text { Non-standard } \\
\text { workers }\end{array}$ & Total \\
\hline Specialised technical work & $75.6 \%$ & $24.4 \%$ & $100 \%$ \\
Managerial work & $92.1 \%$ & $7.9 \%$ & $100 \%$ \\
Clerical work & $69.1 \%$ & $30.9 \%$ & $100 \%$ \\
Sales work & $51.6 \%$ & $48.4 \%$ & $100 \%$ \\
Service work & $29.2 \%$ & $70.8 \%$ & $100 \%$ \\
Security work & $0.9 \%$ & $99.1 \%$ & $100 \%$ \\
Transportation communication work & $60.3 \%$ & $39.7 \%$ & $100 \%$ \\
Production process labour & $47.2 \%$ & $52.8 \%$ & $100 \%$ \\
Others & $9.6 \%$ & $90.4 \%$ & $100 \%$ \\
\hline
\end{tabular}

Source: General Survey on Diversified Types of Employment (2007) and Futagami (2010).

Further, 'non-standard' and 'gender' are highly correlated. Women make up 89.7 per cent of all part-time jobs and 62.1 per cent of all 'despatch' jobs in Japan (2007) as Table 13.6 suggests. Women dominate in part-time and non-standard employment (cf. chapter 9), both as a result of a paternalistic employment system and of a paternalistic tax system (Abe, 2008).ii In addition, there are at least one million foreign workers in Japan, working in a wide range of jobs, and many of them, especially Chinese workers, work informally.

Houseman and Osawa (2003) find that temporary jobs are less likely to be stepping stones to future regular jobs in Japan. Not surprisingly, many temporary agency workers say they would rather be regular, permanent workers. According to Ministry of Health, Labour and Welfare's Survey of the Diversification of Employment Status (2003), while many non-regular workers choose to be so because they are willing to trade compensation and job security for better work schedules, 21.6 per cent of parttime workers and 40 per cent of agency workers worked in non-regular jobs because they could not find a permanent position.

Being in non-standard employment has its disadvantages. A number of Japanese surveys on the working conditions of non-standard workers show that, while they often perform jobs similar to those of regular workers, the wage differentials are widening (JILPT 2008, 2009, 2011). 


\begin{tabular}{|c|c|c|c|c|c|c|c|}
\hline & $\begin{array}{l}\text { Regular } \\
\text { work }\end{array}$ & $\begin{array}{l}\text { Part-lime } \\
\text { work }\end{array}$ & $\begin{array}{l}\text { Temporary } \\
\text { work }\end{array}$ & $\begin{array}{l}\text { Despaiched } \\
\text { work }\end{array}$ & $\begin{array}{l}\text { Contract } \\
\text { work }\end{array}$ & $\begin{array}{l}\text { Entrusted } \\
\text { work }\end{array}$ & Others \\
\hline Fernale & $30.7 \%$ & $89.7 \%$ & $49.5 \%$ & $62.1 \%$ & $48.4 \%$ & $37.8 \%$ & $51.4 \%$ \\
\hline Male & $69.3 \%$ & $10.3 \%$ & $50.5 \%$ & $37.9 \%$ & $51.6 \%$ & $62.2 \%$ & $48.6 \%$ \\
\hline Tota] & $100 \%$ & $100 \%$ & $100 \%$ & $100 \%$ & $100 \%$ & $100 \%$ & $100 \%$ \\
\hline
\end{tabular}

Source: Employment Status Survey (Ministry of Internal Affairs and Communications), Asao (2010).

Table 13.7 Non-standard employment in Korea (2002-2010)

\begin{tabular}{llllll}
\hline Year & \multicolumn{2}{l}{ National Stalistics Office } & & \multicolumn{2}{c}{ Korean Contingent Workers Centre } \\
\cline { 2 - 3 } & Number (Unit: 1,000) & Percentage & Number (Unit: 1,000) & Percentage \\
\hline 2002 & 3,839 & $27.4 \%$ & 7,708 & $56.6 \%$ \\
2003 & 4,606 & $32.6 \%$ & 7,834 & $55.4 \%$ \\
2004 & 5,394 & $37.0 \%$ & 8,130 & $55.7 \%$ \\
2005 & 5,482 & $36.6 \%$ & 8,394 & $56.1 \%$ \\
2006 & 5,457 & $35.6 \%$ & 8,414 & $54.8 \%$ \\
2007 & 5,703 & $35.9 \%$ & 8,576 & $54.0 \%$ \\
2008 & 5,445 & $33.8 \%$ & 8,374 & $52.0 \%$ \\
2009 & 5,754 & $34.9 \%$ & 8,535 & $51.8 \%$ \\
2010 & 5,685 & $33.4 \%$ & 8,550 & $50.2 \%$ \\
\hline
\end{tabular}

Source: Non-standard Work Statistics of Korea Labour Instinte (KLI), Korea Contingent Workers' Centre (KCWC).

If the level of non-standard employment in Japan is sizeable, the rate of growth of non-standard employment in Korea has been much faster, has happened over a shorter period and the levels of nonstandard employment are even higher. Between 1997 (the onset of the Asian Financial Crisis) and 2010, the percentage of employees in various types of non-standard work increased so dramatically that according to some estimates (see Table 13.7) they constitute the largest segment of the workforce.

The differences in wages and benefits between regular workers and nonstandard workers are as large as the differences we have seen in Japan. The employment tenure gap is widening as well, from 69.8 months (regular workers) and 24.1 months (non-standard workers) in 2002 to 77.3 months (regular workers) and 23.6 months (non-standard workers) in 2010. Second, and in contrast to Japan where a significant portion of non-standard work is a result of voluntary choices by women and Freeters, a large proportion of non-standard employment in Korea is involuntary. Surveys indicate that many non-regular workers would like standard jobs, but employers are increasingly avoiding regular employment. The percentage of workers who are forced to work in non-standard jobs increased from 48.5 per cent in 2006 to 55 per cent in 2010. It is also notable that most non-standard employment is considered as 
quasi-permanent, in that most non-standard workers are trapped in their current categories rather than being able to step into regular jobs (Nam and Kim, 2000). Table 13.8 provides some data on the differences between regular and non-standard workers in terms of wages, tenure and benefits.

The growth in the non-standard workforce is mirrored by the growth in the subcontracting of work in the Korean manufacturing industry. Currently 326,000 workers work under subcontracting conditions in numerous industries, including the shipbuilding, electronics, auto, chemical manufacturing and service industries (Kim, 2011). It is noteworthy that both private companies (e.g. Hyundai, LG and Samsung) and state-owned enterprises (e.g. Incheon International Airport Corporation) use subcontracted workers. In the shipbuilding and steel industries, the ratio of subcontracted workers visä-vis regular workers is, respectively, 61 per cent and 43 per cent (Kim, 2011).

\begin{tabular}{|c|c|c|c|c|c|c|c|c|c|c|}
\hline Year & & 2002 & 2003 & 2004 & 2005 & 2006 & 2007 & 2008 & 2009 & 2010 \\
\hline \multirow[t]{2}{*}{ Wage } & Regular worker & 100 & 100 & 100 & 100 & 100 & 100 & 100 & 100 & 100 \\
\hline & Non-standard worker* & $67.1 \%$ & $61.3 \%$ & $65.0 \%$ & $62.7 \%$ & $62.8 \%$ & $63.5 \%$ & $60.9 \%$ & $54.6 \%$ & $54.8 \%$ \\
\hline \multirow{2}{*}{ Tenure (month) } & Regular worker & - & - & 69.8 & 71.8 & 70.1 & 71.3 & 73.9 & 78.6 & 77.3 \\
\hline & Non-standard worker & -1 & - & 24.1 & 23.9 & 25.1 & 26.3 & 24.2 & 21.2 & 23.6 \\
\hline \multirow[t]{2}{*}{ Pension } & Regular worker & $62.9 \%$ & $70.8 \%$ & $72.5 \%$ & $75.7 \%$ & $76.1 \%$ & $76.3 \%$ & $77.3 \%$ & $78.9 \%$ & $78.4 \%$ \\
\hline & Non-standard worker & $25,7 \%$ & $30.5 \%$ & $37.5 \%$ & $36.6 \%$ & $38.2 \%$ & $40.0 \%$ & $39.0 \%$ & $38.2 \%$ & $38.1 \%$ \\
\hline
\end{tabular}

- Percentage of wage of regular worker.

Further, apart from increased subcontracting and the moving of work to lower cost locations in China, there is a significant increase in the number of foreign migrant workers in Korea. The number of foreign workers doubled between 2002 and 2007. Most foreign workers are unskilled workers employed in the labour- intensive sectors, such as construction, service and manufacturing, and they are doing the low-paid, dangerous, dirty and difficult jobs in South Korea. It is estimated that foreign workers account for more than 5 per cent of the total employees. Although they receive legal protection based on Korea's Labour Standard Act, Minimum Wage Law, and the recently enacted Act on Employment of Foreign Workers in 2010, they are still considered to be the most vulnerable, marginalised group in Korea, as these laws are not well enforced. It is this variation in the different types of non-standard workers that accounts for the different estimates of the number of non-standard workers in Korea. Irrespective of the variation however, it is clear that non-standard work has become the 'new normal' in Korea. 
Estimating the quantity of informal work in China is also problematic given that the statistics collected by the government are not very reliable. We know the key source of the growth in informal employment comes from Chinese migrant workers, who work and live in places far away from their home provinces where their hukou (household registration) is located. According to the 2010 census, the size of this 'floating population' was 230 million. Most of these migrant workers rely on hometown networks, labour-contracting companies or other labour 'despatch' agencies when searching for jobs in urban areas. Mostly, they end up working in non-standard employment arrangements, such as temporary work, part-time domestic work, 'despatched' work and subcontracted work. A second key source of temporary labour is student interns. Local governments have expanded vocational schools in anticipation of a future need for skilled workers, and the number of interns has increased from approximately 12.5 million in 2003 to 22 million in 2009 (Liang, 2011). Although student interns are supposed to work under the partial supervision of their vocational high schools, they are increasingly seen as a source of cheap labour by employers. These student workers are usually not covered by written labour-contracts and social insurance benefits because they are 'students', not 'workers'. For example, if work injuries occur, they are not entitled to the government's work injury insurance because they are not workers. Until recently, China has not had laws on legal protection for informal and subcontracted work, and even though a new law was introduced in 2008 (discussed later in this chapter), the implementation of labour laws in China varies dramatically across provinces (Kuruvilla et al., 2011).

As noted, formal estimates of informal work in China are difficult to obtain. The best available estimates are from Park and Cai (2011). They analyse a variety of government data bases and conclude that the number of non-standard workers comprises about 40 per cent of the Chinese workforce, as indicated below. 
Table 13.9 Urban employment by employer type in China

\begin{tabular}{lllllll}
\hline Year & $\begin{array}{l}\text { State- } \\
\text { owned }\end{array}$ & Collective & $\begin{array}{l}\text { Co-operative, } \\
\text { joins, limited } \\
\text { liability, share- } \\
\text { holding } \\
\text { corporations }\end{array}$ & $\begin{array}{l}\text { Private and } \\
\text { self } \\
\text { employed }\end{array}$ & $\begin{array}{l}\text { Foreign } \\
\text { and joint } \\
\text { venture }\end{array}$ & Others \\
\hline 1990 & $61 \%$ & $21 \%$ & $1 \%$ & $4 \%$ & - & $14 \%$ \\
1991 & 61 & 21 & - & 4 & 1 & 13 \\
1992 & 61 & 20 & - & 5 & 1 & 13 \\
1993 & 60 & 19 & 1 & 6 & 2 & 13 \\
1994 & 60 & 18 & 2 & 9 & 2 & 10 \\
1995 & 59 & 17 & 2 & 11 & 3 & 9 \\
1996 & 56 & 15 & 2 & 12 & 3 & 12 \\
1997 & 53 & 14 & 2 & 13 & 3 & 15 \\
1998 & 42 & 9 & 5 & 15 & 3 & 26 \\
1999 & 38 & 8 & 6 & 16 & 3 & 31 \\
2000 & 35 & 6 & 6 & 14 & 3 & 35 \\
2001 & 32 & 5 & 7 & 15 & 3 & 38 \\
2002 & 29 & 5 & 7 & 17 & 3 & 39 \\
2003 & 27 & 4 & 8 & 19 & 3 & 39 \\
2004 & 25 & 3 & 8 & 21 & 4 & 38 \\
2005 & 24 & 3 & 10 & 23 & 5 & 36 \\
\hline 509 & & 5 & & & \\
\hline
\end{tabular}

As Table 13.9 notes, the category of 'other' workers or undocumented workers is a residual after counting the number of workers in formal employment.

It is obvious that the wages, benefits and job security of the informal workforce in China will be substantially below that of permanent workers, although unlike in Japan and Korea there are no statistics to indicate the extent of those differences. The abuses that these workers suffer (e.g. such as unpaid or underpaid wages, no work injury compensation and forced, unpaid overtime work) have been well documented (Lee, 2007). Recent empirical studies indicate that these migrant nonstandard workers receive one-half to two-thirds the wages of regular workers and make up one-third to one-half of the factory workforce in the auto industry (Zhang, 2010). Although by law the ratio of student interns cannot exceed one-third of the workforce in factories, it was reported that 70 per cent of the workers at a Honda factory in Foshan, where a lengthy strike occurred in 2010, were student interns (Liang, 2011). Thus, migrant workers and student interns are emerging as a cheap, convenient source of labour supply in contemporary China.

In summary, the growth of non-standard work (or informal work as we term it in this paper) has increased substantially in the three largest East Asian economies. The growth in the number of such workers has been clear and measured in Japan, with many workers making voluntary choices to work in non-standard employment. In Korea, the growth has been sudden and dramatic and largely involuntary. In China, the growth of informal employment has seen a major spurt since the 1994 Labour Law 
changes, and has been driven largely by the rise in its 'floating 'population. In all three countries, the definitions of such work differ, making comparisons difficult, but it is clear, particularly in Korea and China, that these departures from regular stable employment now encompass the largest proportion of the workforce. Since these temporary, casual, informal, agency and 'despatched' workers are not in regular employment, their employment relations are largely 'external' to the firm. This extemalisation of employment relations poses significant challenges to both traditional unionism, which has not evolved adequate responses to this phenomenon, and government policy, which is only now evolving to take into account these developments. We turn to these issues in the next section.

\section{Responses: apathy, resistance and re-regulation}

The growth in non-standard work exacerbates existing divisions within the working class. Trade unions have been historical protectors of workers, and have in most countries attempted to impose standardisation on wages and benefits. However, in both Japan and Korea (see chapters 7 and 8) the dominance of the enterprise union structure has prevented unions from focusing on these 'externalised' employees. Thus, when HRM strategies in enterprises add temporary, or subcontracted or 'despatched' workers, they are not represented by traditional enterprise unions who focus on their core membership, the permanent workers. Thus, by and large, trade unions in Korea and Japan have been either passive or ineffective in protecting the interests of broadly defined informal workers, with some exceptions. In Japan, RENGO included improvements in the working conditions of non-standard workers in temporary and casual workers. It also has made various attempts to recruit and protect non-standard workers, for instance, by the creation of a Contingent Worker Centre in 2007, thereby contributing to increasing the unionisation rate of part-time workers from 3 per cent in 2003 to 5 per cent in 2009.

Although some industrial unions in Korea have had some success in improving the conditions of non-standard workers in banking, janitorial services and sales, Korean enterprise unions have also focused largely on their permanent workers. As can be seen in Table 13.10 below, even though Korean unions have gradually moved into industry-wide bargaining, they have not substantially increased the organisation of non-standard workers. 
Table 13.10 Union centralisation and unionisation rate for non-standard workers in Korea (2003-2009)

\begin{tabular}{lllllllll}
\hline Year & 2003 & 2004 & 2005 & 2006 & 2007 & 2008 & 2009 & 2010 \\
\hline $\begin{array}{l}\text { Percentage of } \\
\text { industrial } \\
\text { regional union } \\
\text { members }\end{array}$ & $31.3 \%$ & $39.4 \%$ & $40.1 \%$ & $39.7 \%$ & $51.3 \%$ & $52.9 \%$ & $52.9 \%$ & $54.1 \%$ \\
$\begin{array}{l}\text { Union density of } \\
\text { non-standard } \\
\text { workers }\end{array}$ & $2.4 \%$ & $3.1 \%$ & $3.2 \%$ & $2.8 \%$ & $3.3 \%$ & $3.0 \%$ & $2.0 \%$ & $1.9 \% *$ \\
\hline
\end{tabular}

Source: Ministry of Employment and Labour, Korca Contingent Workers' Centre.

In China, official trade unionism has an ambiguous role vis-ä-vis protecting the regular workforce (for exceptions, see Liu, 2010), let alone temporary workers. Largely ignored by the trade unions, the non-standard workforce in all three countries have had to take matters into their own hands. In Korea, non-standard workers went on strike at Ki-Ryung Electronics in 2005, E-Land in 2007 and Dong-Hee Auto in 2008. These three strikes began spontaneously, without union support, but with help from social justice and civil society groups (e.g. the Contingent Workers' Centre in Korea). Similarly, wildcat strikes and spontaneous protests are increasing in China (see Zhu et al., 2011). These include not only strikes in foreign-owned factories, iii but also strikes in domestic and state-owned facilities. ${ }^{\text {iv }}$ In addition, Zhang (2010) documents substantial resistance by temporary and informal workers in the auto industry. In China as well, informal workers use the help of labour-friendly NGOs to help them in resolving their issues and grievances (e.g., SACOM and Little Bird). In other situations, they have taken more drastic steps, such as the suicides in Korea Express in 2009 and China's Foxconn in 2010, to draw the attention of the public to their plight (Shin, 2010, Friedman and Lee, 2010).

The most significant response in these countries has come from the government, in response to the growing and increasingly expressed dissatisfaction of a nonstandard workforce that constitutes a sizeable proportion of the workforce in all three countries. In Japan, an example is the Revised Part-Time Work Act, which was implemented in April 2008. The major provisions include:

- written documentation of employment and working conditions;

- no discrimination regarding equal employment conditions vis-ä-vis regular workers;

- $\quad$ encouragement of employer efforts to move part-time jobs towards regular jobs;

- the government's active engagement in part-time workers' grievance procedures through government agencies (Morozumi, 2009). 
Since the new ruling party (Democratic Party of Japan) took power in August 2009 after campaigning with a strong emphasis on employment issues, they have introduced a new law concerning 'despatch labour' which is under review in the Diet. The overall focus of the law is to limit the use of such labour. Accordingly, the draft law seeks to

- prohibit its registration except in 26 special areas;

- prohibit it in the manufacturing industry;

- prohibit contracts of less than two months when using contingent work.

In addition, the new draft also seeks to render equal treatment to workers doing the same job (whether they are regular or not) and forces staffing agencies who are the primary employers of 'despatched labour' to notify their employees about their rights and working conditions. Thus, the response of the Japanese government has been to 're-regulate'; i.e. produce new regulations to solve problems created by old legislation.

In Korea, after five years of debate among business, labour and the state, the Protection Law on Contingent and Despatch Labour was implemented in 2007. This law, which focuses on the rights and working conditions of 'contingent' and 'despatched' workers, includes two major provisions: it prohibits employers from using the same worker in temporary jobs for more than two years (i.e. the workers must be made permanent thereafter if the job still exists) and also prohibits discrimination. Not only are these provisions contentious, but they have resulted in unintended consequences, as employers have found ways to engage more indirect labour through direct subcontracting. Given that 'despatched' workers are protected by this law, while subcontracted workers have no regulations to protect themselves with, the employer response was to start using diverse in-house subcontracting, with a nominal subcontractor in the records. With the sudden jump in the use of far-externalised employment practices, and the ensuing protests amongst temporary workers and their civil society supporters, the government has tried to respond with both non-mandatory guidelines and stricter regulations. The guidelines, issued in July 2011, suggest that the principal company

- should give subcontractors a month's warning before the job is ended;

- should improve the working conditions of subcontracted workers;

- should share a greater amount of profits with the subcontracting agency;

- should recognise subcontracted workers' rights to unionise; 
- $\quad$ should extend welfare benefits to subcontracted workers.

The normative 'soft law' version of the government's response was strengthened with a new draft 'hard law' effort. This re-regulation initiative, issued in August 2011, proposes to

- prohibit subcontracting in the core work of companies;

- limit the number of subcontracted workers to a proportion of the principal contractor's employee numbers;

- $\quad$ provide them with priority in permanent hiring.

In a similar vein, the Supreme Court's ruling against Hyundai Motor's subcontracting employment in July 2010 has been followed by a series of court rulings at various levels (specifically, about Hyundai Asan in 2010, Korea GM in 2010 and Kumho in 2011). The court ruled in these cases that the companies were using 'disguised subcontracting' (i.e. the illegal use of despatch labour) and forced the companies to transfer the subcontracted worker into regular worker status after two years.

It is in China that we have seen the greatest legislative efforts to control the growing informality of work (Kuruvilla et al, 2011). Under the rubric of a 'harmonious society' (see Warner, 2011) the government implemented a series of labour laws in January 2008 (namely, the Labour-Contract Law, the Arbitration and Mediation Law and the Employment Promotion Law) reinforcing previously nominal IR institutions (e.g. trade unions (the All-China Federation of Trade Unions, ACFTU), collective agreements, wage negotiations and the tripartite system) (see chapter 5 ). These new laws not only provide a modicum of employment security for workers (through a variety of provisions with regard to employment contracts), but they also expand the rights of workers to file claims for arbitration or litigate them and provide unions with legal encouragement to engage in unionisation and collective bargaining. For example, Articles 10 and 82 of the Labour- Contract Law require that the employer must enter into a written labour-contract with a worker within 30 days of employment. Failure to do so leads to the penalty of paying the worker double wages for any time served without a written contract. If employees work for 12 months without a contract, they must be provided with an indefinite term contract (i.e. made permanent). The changes in the Arbitration and Mediation Law are intended to not only speed up the process of dispute resolution but also to extend the time limit during which the aggrieved worker can file for arbitration (from 60 days to one year), and completely eliminate the arbitration fee, while shifting the burden of proof on to the employer. 
Even more far-reaching (relative to efforts in Korea and Japan) are the special provisions in the Labour-Contract Law which try to regulate labour staffing agencies or 'despatch agencies' as well as 'despatched labour'. First, the law requires minimum capital requirements for registration as a staffing agency ( 0.5 million RMB). Second, it specifies that the 'despatch labour' should only be used for temporary, auxiliary or substitute jobs and that the workers are to be remunerated according to the principle of 'equal pay for equal work'. Several articles focus on the division of responsibility between the 'despatching agency' and the employer, specifying that both share responsibilities for some aspects such as dismissal and workplace injuries. The Law also regulates the conditions of part-time workers, noting that part-time work is specified to be less than 4 hours per day and 24 hours per week (Article 68).

China's legislative efforts have been far more comprehensive than those of Japan and Korea, and in the Korean case the legislative effort is still contested. On the other hand, the implementation of the law in China is uneven. The goals of the central state in controlling the growth of informal work have been undermined by the inability or unwillingness of local governments to enforce the law for a variety of reasons, notably the need to attract foreign investment (Kuruvilla et al, 2011). This problem of the enforcement of the law raises the possibility that the Labour-contract Law may have the unintended consequence of driving even more employment underground into the informal sector (Kuruvilla et al., 2011). On the other hand, there is an increased effort in some parts of China to better enforcement, through the efforts of workers, labour-friendly NGOs and local labour bureaux (Cooney, 2011, Kuruvilla et al, 2011).

In summary, in all three countries it is the governments, rather than the trade unions, that have been the prime movers in developing policy to contain the growth of informal work, and to bolster the rights of informal workers. This legislative effort of the governments is suggestive, in our view, of an emerging and competing 'logic of labour protection' (Frenkel and Kuruvilla, 2002).

\section{Conclusions}

What we have identified in this chapter is a clear and significant movement in employment relations and HRM strategies away from stable regular employment to a variety of contingent arrangements in all three countries. These contingent arrangements externalise employment relations at the firm level, creating a new segmentation in enterprise workforces. As such, these new forms of workers do not often come under the purview of bilateral labour relations, as enterprise unions represent only those 
permanent workers directly hired by the employer. In all three countries, these contingent arrangements account for a significant proportion (if not the major proportion) of the workforce. Their growth represents a challenge not only to traditional industrial relations actors, but also for industrial relations scholarship, apart from government policy.

Given the inability of bilateral employment relations to address these issues (either through labour union action or high road HRM strategies), .governments, responding to growing social pressure from these workers, have begun to intervene. In all three countries, the growth in the number of informal workers was the result of government policy and regulations aimed at increasing flexibility. The current efforts represent a significant effort at 're-regulation', i.e. to control the growth of contingent employment unleashed by their prior regulations. It is still too early to estimate the impact of such reregulation, given that it is quite recent, and also given some evidence that these protective laws are having unintended consequences. However, it is evident that there is a clear 'labour protection' logic underlying these efforts. The challenge for workers and trade unions in these countries is how to capitalise on that 'emerging logic'.

\section{References}

Abe, Y. (2008) 'The Effects of the 1.03 million yen Ceiling in a Dynamic Labour Supply Model', Contemporary Economic Policy, 27: 147-63.

Cooney, S. (2011) Dynamism and Stasis: Regulating Working Conditions in China. Presented in the Conference 'Regulating for Decent Work', University of Melbourne, 6 July 2011.

Frenkel, S. and Kuruvilla, S. (2002) 'Logics of Action, Globalization, and Employment Relations Change in China, India, Malaysia, and the Philippines', Industrial and Labour Relations Review, 55: 387-412.

Friedman, E. and Lee, C. K. (2010) 'Remaking the World of Chinese Labour', British Journal of Industrial Relations, 48: 507-33.

Gallagher, M. (2004) 'Time is Money, Efficiency is Life: The Transformation of Labour Relations in China', Studies of Comparative International Development, 39: 11^-4.

Houseman, S. and Osawa, M. (2003) 'The Growth of Nonstandard Employment in Japan and the United States: A Comparison of Causes and Consequences' in Houseman, Susan and Osawa, Machiko (eds) Nonstandard Work in Developed Economies: Causes and Consequences. Kalamazoo, Michigan: W. E. Upjohn Institute, pp. $175-214$.

Hurst, W. (2009) The Chinese Worker After Socialism. Cambridge: Cambridge University Press. JILPT (Japan Institute for Labour Policy and Training) (2008) Labour Situation in Japan and Analysis. Tokyo: JILPT.

- (2009) Labour Situation in Japan and Analysis. Tokyo: JILPT.

- (2011) Labour Situation in Japan and Analysis. Tokyo: JILPT. 
Jung, E. and Cheon, B-Y. (2006) 'Economic Crisis and Changes in Employment Relations in Japan and Korea', Asian Survey, 46: 457-76.

Kim, D-O. and Kim, S. (2003) 'Globalization, Financial Crisis, and Industrial Relations: The Case of Korea', Industrial Relations, 42: 341-67.

Kim, I. (2011) An Investigation Report on Subcontracting Practices in Korea, Hankyoreh Shinmun (newspaper), 10 October, p. 1

Kuruvilla, S., Lee, C-K. and Gallagher, M. (2011)From Iron Rice Bowl to Informalization: Markets, Workers, and the State in a Changing China. Ithaca NY and London: ILR Press.

Lee, J. (2011) 'Between Fragmentation and Centralization: South Korean Industrial Relations in Transition', British Journal of Industrial Relations, 42: 1-25.

Lee, C-K. (2007) Against the Law: Labour Protests in China's Rustbelt and Sunbelt. Berkeley CA: University of California Press.

Liang, S. (2011) Cheap Labour in Essence, Students in Name: Vocational School Interns in China. Hong Kong: Asia Monitor Resource Centre, September 2011.

Liu, M-W. (2010) 'Organizing in China: Still a Monolithic Labour Movement?’, Industrial and Labour Relations Review, 64: 30-52.

Morozumi, M. (2009) 'Balanced Treatment and Bans on Discrimination: Significance and Issues of the Revised PartTime Work Act', Japanese Labour Review, 6: 39-55.

Nam, J. and Kim, Tae-Ki. (2000) 'Non-regular Labour, Bridge or Trap?', Korean Journal of Labour Economics, 23: 85105.

Ono, H. (2010) 'Lifetime Employment in Japan: Concepts and Measurements', Journal of the Japanese and International Economies, 24: 1-27.

Park, A. and Cai, F. (2011) 'The Informalization of the Chinese Labour Market' in Kuruvilla, S., Lee, C. K. and Gallagher, M. (eds) From Iron Rice Bowl to Informalization: Markets, Workers, and the State In a Changing China. Ithaca, NY and London: Cornell University Press.

Reiko, K. (2006) 'Youth Employment in Japan's Economic Recovery: "Freeters" and "NEETs" ', Japan Focus, May.

\footnotetext{
' Note that our use of the term 'employment relations systems' includes the variety of labour relations and human resource institutions, policies and practices.

ii If a married woman works part-time and earns less than 1.03 million yen annually, her husband is eligible to receive several types of benefits. These include 1) her social security and health care benefits under her husband's
} 
coverage, 2) her exemption for income tax, and 3) an allowance for a low-income spouse from his employer (Abe, 2008).

iii Examples include strikes in Japanese Honda Auto (2010), Taiwanese Wintek (2010), Korean Sungwoo (2010) and American Pepsico Bottling (2011).

iv Examples include a strike in Tonggang Steel (2010), a railway worker strike in Changsha (2011) and a hospital custodian strike in Shanghai (2011). 